tion for making the section a permanent part of the department. New developments in this section included the construction of a $35 \mathrm{ft}$. tower at the Central Agricultural Meteorological Observatory, for the study of exchanges of heat and moisture between. the surface layers of the soil and the atmosphere. The Calcutta office issued storm warnings during sixteen periods of disturbed weather over the Bay of Bengal. The outstanding cyclone of the year in that region was that of October 5-12, 1938, which on approaching land caused much damage and some loss of life in the Ganjam district when sea waves inundated the coastal areas and swept away houses and cattle. The Poona office had a greater number of disturbed periods to deal with over the Arabian Sea, and one cyclone redeveloped into a very severe storm early in October after having weakened during its passage across the Peninsula from the Bay of Bengal.

\section{The Bureau of Human Heredity}

The Bureau of Human Heredity is carrying on, though with reduced activity, during the War. Although some international connexions are cut off, a compensation is the possibility of obtaining a median sample of the population through the careful examination of entrants for the Services. This is not to be lost sight of, as collaboration with medical men in examining and collating genetical conditions would be of great importance in furnishing figures of medical, anthropological and genetical value. Although the Bureau has lost several workers, it has enlisted the support of Prof. F. A. E. Crew as honorary medical secretary. Correspondence with men of science in other countries continues, but in diminished volume, which may give time for other projects, including (1) surveys of the genetic background in tuberculosis, (2) the human analogue of the transmission of cancer in animals, (3) certain immunological problems. It is hoped also to compile a preliminary list of inherited disorders and defects based on recent research for the use of practitioners and teachers. The address of the Bureau is 115 Gower Street, London, W.C.1.

\section{Cereals for Spring Sowing}

THE National Institute of Agricultural Botany has just issued a war-time leaflet (Farmer's Leaflet, No. 2, "Varieties of Cereals for Spring Sowing"). Its appearance is opportune, for it both presents an epitome of spring oats and barley in the light of their general utility, as well as their possible substitution on land which was primarily intended for wheat, but which may yet be unsown owing to unfavourable weather. There are also some varieties of wheat normally used for autumn sowing which can be sown up to the end of February with reasonable chances of success. Quality in home-grown wheat at the moment is in abeyance; but other things being equal, the same condition does not apply to oats. These are mainly intended for consumption on the farm, and the value of oat grain for all forms of stock feeding is determined by the amount of husk the grain contains. Thus, where the farmer is in a position to exercise a preference, it should be in favour of a variety with as thin a husk as possible.

In recent years nothing has happened to impair the reputations of Spratt-Archer and Plumage-Archer barleys amongst farmers and maltsters, and in general the recommendation of these varieties cannot be improved upon. There is, however, a case for the Danish varieties Kenia and Maja on rich soils, since both these barleys are early in ripening and both possess shorter and better standing straw than either of the two varieties mentioned above. On less rich soils, and where earliness in ripening is a requisite, the native varieties Standwell and Maltster may be utilized with advantage. Copies of the leaflet may be obtained from the Secretary, National Institute of Agricultural Botany, Huntingdon Road, Cambridge.

\section{Mr. A. H. Mackmurdo}

THE communication entitled "The Social Organism", printed on p. 187 of this issue, has additional interest in the age and associations of the author. Mr. Mackmurdo, who is eighty-nine years of age, is believed to be the only man living who can claim to have been a friend both of Charles Darwin and of Herbert Spencer. For many years he worked with Spencer, and seventy years ago, at the age of nineteen years, he began his subscription to NATURE at the suggestion of Charles Darwin.

\section{Announcements}

Captain Robert Kemp has won the Buckston Browne prize for 1939 with an essay on the value of periodic medical examination in middle life.

Dr. Etienne Burnet, director of the Pasteur Institute of Tunis, has been made a Commander of the Legion of Honour.

Dr. C. G. DarWIN will deliver the thirty-first Kelvin Lecture of the Institution of Electrical Engineers on April 25, at 6 p.m. The title of Dr. Darwin's lecture will be "Thermodynamics and the Coldest Temperatures".

Messrs. W. and R. Chambers, Ltd., announce the early publication of "Chambers's Technical Dictionary". This single volume work contains terms drawn from many branches of scientific and industrial activity, and is under the editorship of C. F. Tweney and Dr. L. E. C. Hughes.

IN memory of the late Prof. V. R. Williams, the Russian authority on soils, the Timiryazev Agricultural Academy in Moscow has founded three annual prizes to be awarded for the best work on soil study and cultivation. The first prize is of 5,000 roubles, the second of 3,000 roubles and the third of 1,500 roubles. The Commissariat of Agriculture is preparing for publication a complete collection of Prof. V. R. Williams' work. New editions of the most important of them will be published this year. 